\title{
MOEBIUS SYNDROME: CHALLENGES OF AIRWAY MANAGEMENT
}

\author{
Ivana Budić ${ }^{1,2}$, Dušan Šurdilovići, ${ }^{1,3}$, Anđelka Slavkovići,4, Vesna Marjanović², Marija Stevićc \\ and Dušica Simić 5,6
}

\begin{abstract}
${ }^{1}$ Medical Faculty, University of Niš; ${ }^{2}$ Centre for Anesthesiology and Resuscitation, Niš Clinical Centre; ${ }^{3}$ Department of Preventive and Pediatric Dentistry, Clinical Department of Dentistry; ${ }^{4} \mathrm{Clinical}$ Department of Pediatric Surgery and Orthopedics, Niš Clinical Centre, Niš; ${ }^{5}$ University Children's Hospital; ${ }^{6}$ Medical Faculty, University of Belgrade, Belgrade, Serbia
\end{abstract}

\begin{abstract}
SUMMARY - Moebius syndrome is a rare nonprogressive congenital neurological disorder with a wide range of severity and variability of symptoms. This diversity is a consequence of dysfunction of different cranial nerves (most often facial and abducens nerves), accompanying orofacial abnormalities, musculoskeletal malformations, congenital cardiac diseases, as well as specific associations of Moebius and other syndromes. The authors present anesthesia and airway management during the multiple tooth extraction surgery in a 10-year-old girl with Moebius syndrome associated with Poland and trigeminal trophic syndromes.
\end{abstract}

Key words: Moebius syndrome; Anesthesia; Airway management

\section{Introduction}

Moebius syndrome is a rare, nonprogressive neurological disorder (prevalence is estimated to be $0.002 \%$ of births or 1 case per 50,000 newborns) characterized by a wide range of severity and variability of symptoms ${ }^{1}$. The classic feature is characterized by unilateral or bilateral facial paralysis and defective extraocular eye movements secondary to congenital paresis of the facial (VII) and abducens (VI) cranial nerves, often accompanied by hypoglossal (XII), trigeminal (V), glossopharyngeal (IX) and vagal (X) nerve palsies. Moebius syndrome may also occur in association with various craniofacial (mandibular hypoplasia, microstomia, temporomandibular joint dysfunction, cleft palate, external ear deformities), limb (clubfoot) and musculoskeletal malformations (Poland anomaly -

Correspondence to: Assist. Prof. Ivana Budic, $M D, P h D$, Kralja Stevana Prvovenčanog 42, 18000 Niš, Serbia

E-mail: ibudic@open.telekom.rs; ibudic@mts.rs

Received February 28, 2015, accepted September 13, 2015 absence of pectoralis major muscle). Other associated manifestations include seizure disorders, congenital heart diseases, hypotonia, hypogonadotropic hypogonadism, hydrosyringomyelia, and some degree of mental retardation ${ }^{2}$.

The cause of Moebius syndrome is unknown, but rhomboencephalic maldevelopment and brainstem ischemia between 5 to 8 weeks of gestation ${ }^{3}$ are two possible etiological hypotheses in children with normal karyotype. The list of potential associated teratogenic events includes hyperthermia, trauma, thrombus formation, embolism, hemorrhage, as well as in utero exposure to various medications including misoprostol ${ }^{4}$. The inheritance patterns of Moebius syndrome are heterogeneous and can be autosomal recessive, autosomal dominant or even $\mathrm{X}$-linked.

Moebius syndrome has multiple implications for anesthesia care, most notably that of airway management ${ }^{5}$, especially when it is associated with other rare clinical conditions such as trigeminal trophic syndrome (TTS) in our case. 


\section{Case report}

A 10-year-old girl with Moebius syndrome was scheduled for multiple tooth extraction surgery. The child had a wide range of characteristic clinical expressions such as mask-like facies, strabismus, severe hypotonia, microglossia, micrognathia, high palate, limited mouth opening, inadequate coughing and swallowing reflexes, and respiratory problems due to frequent aspirations. Unusual clinical manifestations were progressive nasal ulceration, crescent-shaped ulceration at the right corner of the mouth, and trophic changes of the skin bilaterally along the third division of the trigeminal cranial nerve (Fig. 1). Further deficits included hypoplastic corpus calosum, ventriculomegaly, developmental delay, limb anomalies (clubfoot) and hypoplastic right pectoral muscle (Figs. 2 and 3 ).

According to the previous anesthetic chart (anesthetic management for left femoral fracture) sevoflurane-nitrous oxide anesthesia administered through a face mask was used. As a result of reduced temporomandibular joint movement, receding mandible

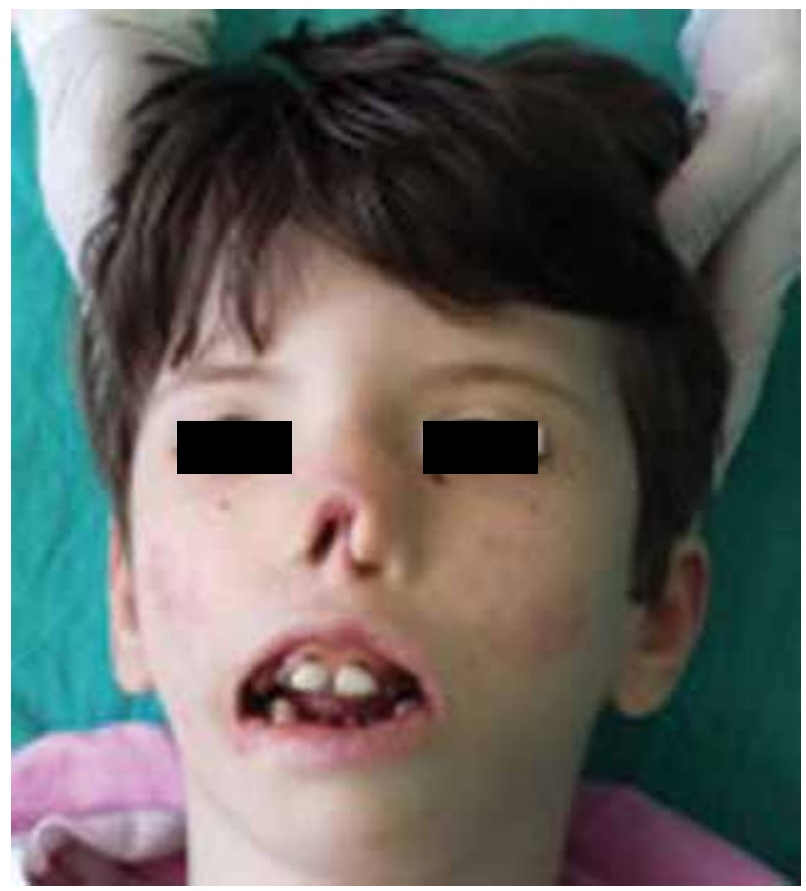

Fig. 1. Clinical characteristics of the patient with Moebius syndrome; extensive nasal ulceration with secondary involvement of the lower lip and trophic changes of the skin are clinical features of the trigeminal trophic syndrome. and alveolar protrusion, Mallampati class was 4 and difficult intubation was predicted. The child was premedicated with atropine $\left(0.01 \mathrm{mg} \mathrm{kg}^{-1} \mathrm{IM}\right)$ and midazolam $\left(0.1 \mathrm{mg} \mathrm{kg}^{-1} \mathrm{IM}\right)$. After the co-induction of anesthesia with sevoflurane (8 vol. \%) supplemented with propofol $\left(1.5 \mathrm{mg} \mathrm{kg}^{-1}\right)$, mask ventilation was successful and orotracheal tube (reinforced endotracheal tube with cuff No. 4.5) was placed uneventfully using external laryngeal manipulation, along with the use of intubation stylet $(2.6 \mathrm{~mm}$, with adjustable stop and round tip), straight laryngoscope blade No.2 with small handle and two-person technique (one anesthesiologist performed laryngoscopy and pushed the larynx into view, while the second one intubated the trachea). Anesthesia was maintained with inhalation of sevoflurane (3-4 vol. \%) and nitrous oxide (65\%). Pre-emptive analgesia was achieved with rectal paracetamol $\left(20 \mathrm{mg} \mathrm{kg}^{-1}\right)$. Rescue analgesia was provided by single bolus doses of alfentanil $\left(10 \mathrm{mcg} \mathrm{kg}^{-1}\right)$. Eleven teeth were extracted and four filled during the procedure that lasted $2.5 \mathrm{~h}$. Following tooth extraction, gelatin-base surgical sponge was applied topically as an adjunct to hemostasis. Extubation was car-

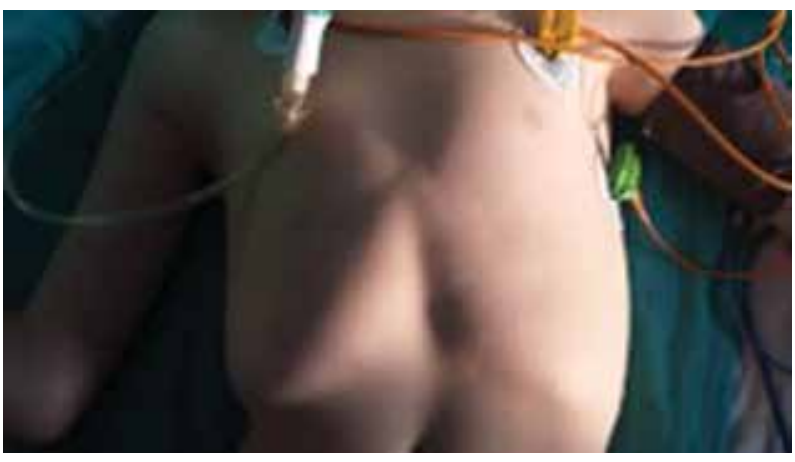

Fig. 2. Hypoplastic right pectoral major muscle.

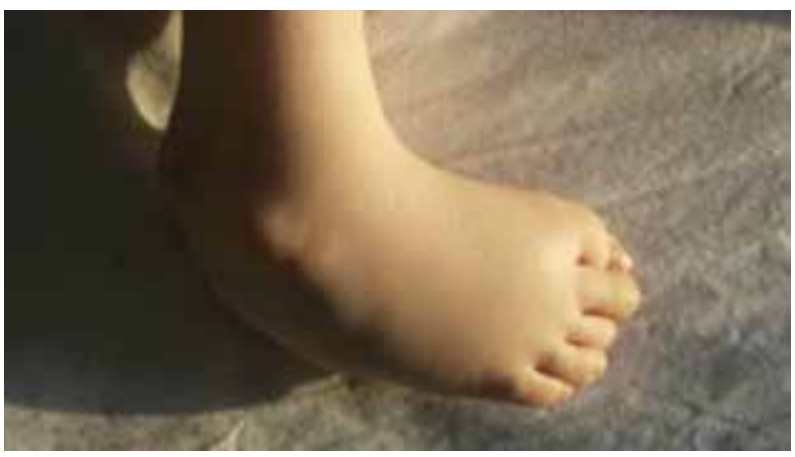

Fig. 3. Clubfoot in our patient with Moebius syndrome. 


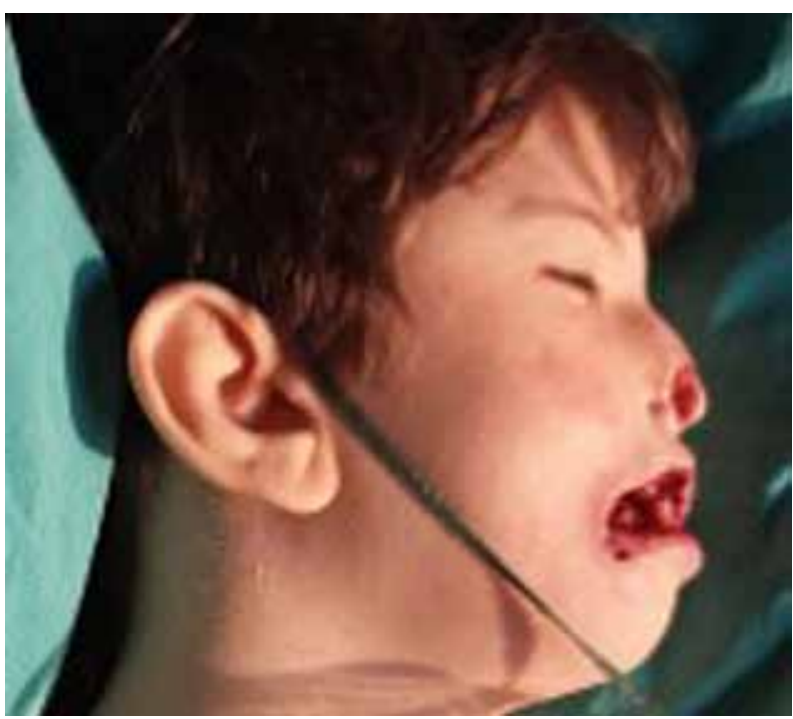

Fig. 4. Patient at the recovery room, postoperatively.

ried out in the operating room with positive pressure breath at extubation when the child was fully awake in the lateral position.

In the immediate postoperative period, two episodes of oxygen desaturation (less than 93\%) happened as a consequence of excessive secretions and blood in oral cavity that crept into the larynx inducing laryngospasm. Oxygen therapy with a face mask was continued, followed by continuous suctioning due to postoperative bleeding that required additional hemostasis (Fig. 4).

\section{Discussion}

Difficulties encountered in performing oral hygiene procedures because of the restricted tongue and masticatory muscle functions predispose children with Moebius syndrome to the risk of dental caries and periodontal problems ${ }^{6}$. We could not agree with Arpaci et al. that multiple tooth extraction (e.g., more than 10 teeth) is a short-term surgical intervention and that analgo-sedation for this procedure must be taken into consideration as an alternative anesthesia method when difficult airway is anticipated ${ }^{7}$. In our case, difficult airway was anticipated, and everything was prepared according to the algorithm for difficult airway management ${ }^{8}$. Nevertheless, orotracheal intubation with stylet under direct laryngoscopy with straight blade and external laryngeal pressure was performed successfully at third attempt using the two-person technique.

Ames et al. ${ }^{5}$ reviewed 111 anesthesia records of 46 patients with Moebius syndrome who underwent different surgical procedures. Face mask ventilation was easily employed in all patients, while in 76 cases (71.6\% of all intubations) tracheal intubation was uneventful. External laryngeal manipulation alone was required to improve the view with laryngoscopy in $17(16 \%)$ cases. In ten (9.4\%) cases, a combination of measures was needed including cricoid pressure, the usage of stylet, two-person technique, and changing of the laryngoscope blade. Fiberoptic intubation was performed in three cases. Only five patients were cancelled due to failed intubation.

Nasal intubation is a preferred technique for oral surgery and offers the surgeon good visualization and satisfactory manipulation of the mouth. In our particular case, due to the extensive nasal ulceration, we decided to perform oral intubation with surgeon's permission.

Nasal ulceration developed as part of TTS by self-induced trauma caused by sensory alteration. The classic clinical triad of TTS consists of trigeminal anesthesia, facial paresthesias, and crescentic lateral ala nasi ulceration. The pathogenesis of TTS is poorly understood ${ }^{9}$, but when associated with Moebius syndrome, it is clear that it represents the consequence of congenital disorder. The question remains what was the trigger for its manifestation at the age of five in our patient.

Our primary concern was extubation because of the inadequate coughing reflex, palatopharyngeal dysfunction (defective swallowing with the tendency to retain oral secretions), laryngeal paralysis and poor spasmodic closure of the glottis, which in the presence of blood could lead to laryngospasm, bronchospasm or aspiration.

Poland anomaly and hypotonia may also have an impact on postoperative respiratory function at different levels: the upper airway, the thoracic musculature and the diaphragm. From all the above mentioned, we decided to avoid muscle relaxants.

Congenital trigeminal anesthesia in children with Moebius syndrome was previously reported in the literature $^{10,11}$. To our knowledge, this is the first described case of Moebius syndrome associated with TTS. 


\section{Conclusion}

Due to the diverse spectrum of clinical findings in patients with Moebius syndrome, standard anesthetic plan for these patients cannot be made in advance. Based on our experience, only careful preoperative evaluation, along with meticulous physical examination can identify the specific end-organ involvement and thereby allow the most optimal plan for airway management in a patient with Moebius syndrome.

\section{References}

1. Verzij1 HT, Van Der Zwaag B, Cruysberg JR, Padberg GW. Möbius syndrome redefined: a syndrome of rhombencephalic maldevelopment. Neurology. 2003 Aug 12;61(3):327-33. doi: 10.1212/01.WNL.0000076484.91275.CD

2. Gondipalli P, Tobias JD. Anesthetic implications of Moebius syndrome. J Clin Anesth. 2006 Feb;18:55-9. doi:10.1016/j. jclinane.2005.05.005

3. Matsui K, Kataoka A, Yamamoto A, Tanoue K, Kurosawa K, Shibasaki J, et al. Clinical characteristics and outcomes of Möbius syndrome in a Children's Hospital. Pediatr Neurol. 2014 Dec;51(6):781-9. doi: 10.1016/j.pediatrneurol.2014.08.011
4. Vauzelle C, Beghin D, Cournot MP, Elefant E. Birth defects after exposure to misoprostol in the first trimester of pregnancy: prospective follow-up study. Reprod Toxicol. 2013 Apr;36:98-103. doi: 10.1016/j.reprotox.2012.11.009

5. Ames WA, Shichor TM, Speakman M, Zuker RM, McCaul C. Anesthetic management of children with Moebius sequence. Can J Anesth. 2005 Oct;52(8):837-44.

6. Shashikiran ND, Subba Reddy VV, Patil R. "Moebius syndrome" a case report. J Indian Soc Ped Prev Dent. 2004 Sep;22(3):96-9.

7. Arpaci H, Kadioglu MN, Tuzuner-Oncul AM. Anesthetic management of a case with Moebius synd rome. Int J Exp Dental Sci. 2012;1(1):37-9. doi: 10.5005/jp-journals-10029-1009

8. Novak-Jankovič V. Management of the difficult airway. Acta Clin Croat. 2012 Oct; 51(3):505-10.

9. Rashid RM, Khachemoune A. Trigeminal trophic syndrome. J Eur Acad Dermatol Venereol. 2007 Jul;21(6):725-31.

10. Iyer A, Hassan E, Newman W, Kneen R. Congenital trigeminal anaesthesia: a rare preventable cause of visual loss in children. BMJ Case Rep. 2012 Jul3;1-5. doi:10.1136/ bcr.03.2012.5955

11. Smith JH, Cutrer FM. Numbness matters: a clinical review of trigeminal neuropathy. Cephalalgia. 2011 Jul;31(10):113144. doi: $10.1177 / 0333102411411203$

Sažetak

\section{MOEBIUSOV SINDROM: IZAZOV ZA ZBRINJAVANJE DIŠNOGA PUTA}

\section{Budic, D. Šurdilović, A. Slavković, V. Marjanović, M. Stević i D. Simić}

Moebiusov sindrom je rijedak kongenitalni neprogresivni neurološki poremećaj obilježen širokim rasponom težine i varijabilnosti simptoma. Ova raznolikost je posljedica disfunkcije različitih kranijskih živaca (najčešće facijalnog i abducentnog živca), pratećih orofacijalnih abnormalnosti, muskuloskeletnih malformacija, prirođenih srčanih mana, kao i specifičnih asocijacija Moebiusovog i drugih sindroma. Autori opisuju anesteziološke postupke i zbrinjavanje dišnoga puta tijekom višestruke ekstrakcije zuba kod desetogodišnje djevojčice s Moebiusovim sindromom udruženim s Polandovim i trigeminalnim trofičkim sindromom.

Ključne riječi: Moebiusov sindrom 1; Anestezija; Zbrinjavanje dišnoga puta 